\title{
Corporate Social Responsibility (CSR) in the Hospitality
}

\section{Industry: Challenges and Practices in São Luís, Maranhão, Brazil}

\author{
David Leonardo Bouças da Silva \\ Federal University of Maranhão (UFMA), São Luís, Brazil \\ Universidade de Brasília (UnB), Brasília, Brazil \\ Luciana Brandão Ferreira, Davi Alysson da Cruz Andrade \\ Federal University of Maranhão (UFMA), São Luís, Brazil \\ University of São Paulo (USP), São Paulo, Brazil
}

\begin{abstract}
This article aims to identify the challenges in the hospitality industry in São Luís, Maranhão, Brazil, with the perspective of developing an organizational culture that enables the practice of corporate social responsibility (CSR). This study method was qualitative, exploratory, and descriptive (Richardson, 1999). The data were collected by interviews with leaders of national and international chain operating hotel companies in São Luís (June 2013), using the technique of content analysis. The theoretical framework was developed upon the concept of human resources management (HRM) and CSR. The research findings confirm that CSR is considered as a business strategy and that it contributes to personal and professional fulfillment of employees due to the offer of some benefits, such as remuneration and career plans, pleasurable work environments, awards, and recognition. Beyond that, findings also revealed that the hotels develop CSR activities, particularly focusing on employees, in order to provide guests' satisfaction. The main conclusions are: (1) Leadership is essential to build a culture that leads to a collective involvement in CSR actions; and (2) HRM is considered as a strategic tool for the development of CSR.
\end{abstract}

Keywords: corporate social responsibility (CSR), human resources management (HRM), hospitality industry, São Luís, Brazil

\section{Introduction}

Corporate social responsibility (CSR) issue has been, increasingly, highlighted in global societies, due to the growth of environmental concern and improvement of environmental legislation around the world,

David Leonardo Bouças da Silva, professor, Tourism and Hospitality Department, Federal University of Maranhão (UFMA); doctoral student in Administration (FACE), master in Sustainable Development (CDS), Universidade de Brasília (UnB).

Luciana Brandão Ferreira, professor, Tourism and Hospitality Department, Federal University of Maranhão (UFMA); master in Administration (FEA), doctoral student in Administration (FEA RP), University of São Paulo (USP).

Davi Alysson da Cruz Andrade, professor, Tourism and Hospitality Department, Federal University of Maranhão (UFMA); doctoral student in Administration (FEA), University of São Paulo (USP), master in Development and Environment (UFPB).

Correspondence concerning this article should be addressed to Prof. David Leonardo Bouças da Silva, Av. Dos Potugueses, 1965, Cidade Universitária, Centro de Ciências Sociais, Departamento de Turismo e Hotelaria, Bloco A, Sala 203, CEP 65080-805, São Luís, Maranhão, Brazil. Email: davidboucasufma@gmail.com. Mobile: + 559881221604. 
motivated by the discourse of sustainable development (Montibeller Filho, 2004). In many countries and marketplaces, organizations advanced in adopting social and environmental measures as business strategies, a situation that should lead business competitiveness for the upcoming years (Figueira \& Dias, 2011).

Hereupon, the human resources management (HRM) approach also gains popularity, due to the advance of strategic thinking, whose focus is no longer restricted to the processes, and directs itself to the organizational routine reflected on the performance and well-being of its employees and other stakeholders ${ }^{1}$ (Rocha-Pinto, Pereira, Coutinho, \& Johann, 2007).

Regarding the hospitality industry, especially in Brazil, the practice of CSR still requires greater commitment of the hotels in reducing negative impacts on the environment, improving environmental awareness, and offering a better quality of life to internal and external clients and society as a whole. Thus, the involvement of employees at different strategic levels becomes an indispensable situation for the establishment of sustainability as an intrinsic value of the organization.

Therefore, the main discussion of this article is to comprehend that in order to develop CSR, the following are imperative: (1) the leaders' commitment to implement CSR; (2) the employees' engagement in the conduction of socio-environmental activities; and (3) an organizational culture that encourages collective efforts with the company's goals, transcending employees' main responsibilities.

In this broad overview, the purpose of this study is to identify the hospitality industry challenges in São Luís, Maranhão, Brazil, to develop an organizational culture that enables the practice of CSR. The specific objectives of this research are: to investigate the comprehension of the leaderships from national and international chains operating hotel companies placed in São Luís about CSR and HRM; to understand how these companies perform CSR activities and HRM; and to provide insights about how to stimulate CSR improvements to the hospitality industry in São Luís, Maranhão.

Methodologically, this exploratory, descriptive, and qualitative approach comprehends an investigation with five national and international chains operating hotel companies placed in São Luís, in June of 2013. Data about CSR and HRM were collected in semi-structured interviews with professionals in leadership positions. The data collected allowed the interviewees' statements analysis and, consequently, leader's overviews.

\section{CSR}

\section{History and Concepts}

In times past, the "social responsibility” was related to philanthropic practices. Andrew Carnegie, in 1899, established the classical approach of CSR in large companies, based on the principles of charity and custody (Stoner \& Freeman, 1985). In 1953, Bowen proposed the concept that organizations had to implement policies and make decisions or follow goals that are desirable in terms of the objectives and values of the society (Bowen, 1957). Meanwhile, some authors, such as Milton Friedman, suggested that a company's responsibility was only to maximize profits, pay its taxes and employees. Other scholars argued that organizations must pay a social counterpart (Correa \& Medeiros, 2008).

\footnotetext{
${ }^{1}$ Stakeholders are the individuals, groups, and other organizations that have a direct interest in how well an organization performs. A basic list of stakeholders for any organization would begin with the employees and contractors who work for the organization, customers and clients who consume the goods and services, suppliers of needed resources, owners who invest capital, regulators in the form of government agencies, and special-interest groups such as community members and activists (Schermerhorn, 1999).
} 
In Brazil, discussions about CSR evolved since the 1960s along with the creation of the Christian Business Leaders Association. The social responsibility movement is highlighted, especially in the 1990s, due to the participation of non-governmental organizations, research institutes, and companies sensibilized to the CSR cause (Schroder \& Lourenço, 2003).

The theoretical framework that references this article is based on Schermerhorn (1999, p. 78) who defined CSR as "an obligation of the organization to act in ways that serve both its own interests and the interests of its stakeholders, representing society at large”. Thus, social responsibility practices begin when the company assumes an ethical commitment to its stakeholders (Melo Neto \& Froes, 2001).

Based on the pyramidal model of Archie Carroll, CSR is subdivided into four types: economic, legal, ethical, and discretionary (philanthropic). Economic responsibility relates to the ability to produce goods and services that society needs, at a cost that guarantees business activities and financial obligations to investors, tributes, and employees. Legal refers to the appropriate behavior of respecting firms' legal obligations. Ethical involves behaviors non-prescribed by the law, but expected and accepted by the society. Discretionary or philanthropic responsibility is voluntary and is motivated by the organizational culture, instead of legal, economic, or ethics obligation (Carroll, 1979).

According to this assumption, CSR definition is a complex pursuit, since the true social responsibility policy involves a range of actions that comprehend the purpose of sustainability itself: to ensure in the long term the natural resources, human being's quality of life, and economic growth (Kruglianskas, L. A. Aliglere, \& L. Aliglere, 2009).

According to Melo Neto and Froes (2001), the mere fact of the company's support to the development of the community and the preservation of the environment are not enough to attribute to it the condition of “socially responsible”. It is essential to ensure employees' well-being, transparent communication, return on shareholders' investments, synergy with suppliers, and customer satisfaction.

It is interesting to highlight the speech, the importance of the employees on the process of development of CSR. This study assumes that employee's well-being has a deep correlation with the quality of services, especially within the tourism and hospitality industry. In general, the literature surveyed emphasizes an approximation of social responsibility and sustainability concepts, in a way that in both, the scholars advocate the necessity of actions inside and outside the firms, including economic concerns from profitability and competitiveness to socio-ecological issues, conducted by legal obligations or cultural behaviors in the organizations.

\section{CSR as a Competitiveness Advantage}

According to Lage and Milone (2001), tourism activities impose social and environmental costs on a destination and its residents. The growth of tourism can cause natural and cultural damage of the tourism region. In these terms, hotels placed in tourist destinations can generate social and environmental impacts on the surrounding community, positive and negative ones. Such impacts can be minimized in a way to bring profits to companies by reducing costs and improving their public images. The arguments against CSR include the fear that its implementation dilutes business purpose and gives the corporation too much social duties (Schermerhorn, 1999).

Thus, CSR can influence the organization image in the marketplace and hence the expectations of customers and their consumption decisions. On the other hand, CSR conduces to the experience within the hotel, because it impacts employee's attitudes while affecting, positively, service quality and the relationship with customers. 
Another important matter is the grown level of people's awareness, which makes them more conscious about their buying decisions. Moreover, the increasing number of corporations means more competition and options for these consumers. To Alves and Conto (2009), among other things, CSR activities, especially environmental actions, are practices that customers take into consideration when they choose their hotel options.

Therefore, tourism and hospitality businesses, which depend on the touristic demand and also have the responsibility for the maintenance of touristic attractions, can be benefitted from these actions and face them, strategically, as a competitive advantage. To Judge and Douglas (1998), there is a positive relation between the incorporation of natural environment issues in the strategic planning and corporate financial performance.

In the hospitality industry, there are interesting examples of CSR activities. From the first point of view, this practice can influence the relationship with clients/customers in two ways: initially, through internal social responsibility which addresses actions to their employees, based on education and training, benefits, and professional recognition and development; the second aspect is concerned with external social responsibility, in other words, activities related to the external stakeholders, such as consumers, surrounding community, suppliers, government agencies, and local environment.

The successful implementation of a strategy depends on the company's ability to develop it. Indeed, the strategic planning must involve CSR variables as a way to ensure the inclusion of sustainability in the strategic management of organizations (Coral, 2002).

According to Guedes (2000), CSR programs promote varied social returns to the companies, such as best public image due to the brand strengthening and loyalty, relationship improvement between the companies and investors, advertising return through spontaneous media, tax exemptions, society behavioral changes, and productivity due to the increase of employees' commitment and motivation. Thus, it is worth to emphasize that the employees' commitment is essential for CSR execution.

\section{HRM and Its Contributions to Organizational Culture Changes}

\section{HRM and Organizational Culture}

The business environment context reflects extensive changes in contemporary societies, mainly related to globalization, information technology, emergence of new values as a reference for happiness, and evolution of a paradigm established on the quality of life traduced on the exercise of citizenship and personal achievements (Vergara, 2005).

In the last years, knowledge has overcome financial capital as an essential step to organizational success beyond labor market competitiveness that requires professional training which is no longer comprehended as training for specific operations, but a systematic development of skills known as competences ${ }^{2}$ (Rocha-Pinto et al., 2007).

Leadership performance is responsible for the consolidation of organizational culture as well as for the mission, vision, and goals of the companies. Leaders must also consider intangibles aspects (sadness, lack of motivation, and family concerns among others) and stimulate emotional intelligence, as an essential skill, as soon as a human vision of nature that ignores the power of emotions is woefully shortsighted. When it comes to shaping our decisions and actions, the feeling counts exactly the same or more than the thought (Goleman, 1995).

\footnotetext{
${ }^{2}$ Competence is a group of knowledge, skills, and attitudes that affect most of the employees' jobs and are concerned with their performance (A. C. Fleury \& M. T. L. Fleury, 2000; Rocha-Pinto et al., 2007).
} 
From this perspective, a holistic approach must be considered to provide qualitative gains. Employees, in order to perform according to the companies and consumers' requirements, demand labor rights, but essentially, consideration for their emotional and psychological issues.

Therefore, the following functional dimensions of HRM elucidate the discussion above: recruitment and selection, recognition and strategic remuneration, performance evaluation, competencies certification, and organizational culture (Rocha-Pinto et al., 2007). These dimensions contribute to promoting employees' personal and professional satisfaction through the development of their competencies, skills, and attitudes, as well as to improving the quality of products and services.

Conceptually, organizational culture can be defined as a set of beliefs, symbols, and values shared by a group of people (Barbosa, 2009; as cited in Tonet, Bittencourt, Costa, \& Ferraz, 2012) and it is considered as an intangible dimension of HRM. The organizational culture deserves more attention, because it will guide the corporate behavior beyond economic, socio-political, and environmental issues that arise in everyday business.

Ideally, companies would have sustainability as an intrinsic value, by developing socio-environmental measures. Although, only a deep change in organizational culture, which requires a proper posture of leaders and their abilities to manage corporation talents, can lead to the critical awakening and the adoption of sustainable practices. This situation would set up a practical difference between "being responsible" and "act responsible".

This way, the establishment of an organizational culture requires the commitment and involvement of all sectors within the organization, instead of creating internal subcultures with environmental concerns (Dias, 2009). Therefore, CSR demands the engagement of all the leaders and employees recognizing their roles in the development of a socio-ecological culture committed to sustainability.

\section{HRM in the Tourism Industry}

Travelers, usually, construct their impressions on intangible perceptions, such as warmth and hospitality, to infer their point of views about the quality of services in tourist destinations. Based on this assertion, every company in the tourism industry which wants to be competitive needs an HRM program to develop a better attitude in their employees (Pimenta, 2006).

However, in Brazil, leaders in the tourism and hospitality industry face challenges to provide a motivational environment and to lead employees to achieve business goals, due to low remuneration, professional competitiveness in tourism industry, and expressive turnover caused by seasonality. At this point, these companies have to improve their employees' treatment and recognition, because these gaps result in tourist dissatisfaction and its consequent negative perceptions.

Therefore, nowadays, talent management is one of the main barriers to the tourism industry, especially to ensure conditions to develop their skills, fulfill their achievements, and gain recognition on the tasks assigned to them.

Any conceptual approach understands tourism and its various forms as a social interaction activity (Dias, 2008). This way, employees have more responsibilities in promoting a qualified service, because consumers easily identify mistakes and notice the negative aspects of destinations (Pimenta, 2006).

In the hospitality industry, regardless of the kind of accommodation, from economic to luxury, its target audience demands high quality level of products and services. The companies must follow international 
standards in terms of services, comfort, safety installations, and nowadays, social and ecological impacts on the environment and people. In the 2014 World Cup and 2016 Olympics scenario, Brazil needs to focus carefully on this concern.

CSR and HRM themes are correlated, because both of them must be intrinsic elements of the organizational culture in the modern tourism industry, and at the same time, HRM provides the basis for CSR practices. In other words, for a CSR initiative, leaders need to motivate employees to get involved with the implementation of sustainable activities, such as environmental management and social programs with local communities reaching, this way, the organizational goals.

In the following lines, this study advances in the discussion of CSR and HRM aiming to understand the challenges in the hospitality industry of São Luís, Maranhão, Brazil, to develop an organizational culture in the hotels investigated that allows CSR development.

\section{Challenges From Organizational Changes in the Hospitality Industry of São Luís, Maranhão, Brazil}

\section{Research Scenario}

São Luís, Maranhão, is a coastal Brazilian city with a population of more than 1 million inhabitants (Instituto Brasileiro de Geografia e Estatística [IBGE], 2010), and it stands in the tourism scenario of Brazilian northeast, focusing both on cultural and events/business tourism. The city, despite the problems with tourism offer (urban infrastructure, tourist attractions, and workforce), has grown in visitors' arrivals over the past few years $^{3}$, reflected by the increase of public and private investments to support new services within the tourism and hospitality industry. From 2002 to 2011, hotels’ room offers increased more than 100\%, reaching 4,700 rooms (Maranhão, 2009).

This growth can be explained, particularly, due to: (1) São Luís historic downtown is listed as a UNESCO (United Nations Educational, Scientific, and Cultural Organization) world heritage site; (2) cultural richness of the local festivities of São João ${ }^{4}$; (3) the improvement of local conditions to support events (hotels, auditoriums, and growth of convention centers); and (4) the attraction of public and private investments that stimulate business opportunities.

Regarding the local hotel market, there has been a diversification of its offer traduced by the arrival of national and international hotel corporations, whose management models seek to follow more structured and demanding standards, which requires a continuous improvement over the entire HRM process.

\section{Research Method}

Methodologically, this is a qualitative, exploratory, and descriptive study (Richardson, 1999). The research universe is made up of hotels of national and international chain operating companies placed in São Luís, Brazil, comprehending 11 hotels. The investigation focused on five of these companies ${ }^{5}$ and its leaders (mainly managers). The field research happened in June of 2013 (see Table 1).

\footnotetext{
3 Excepting years that externalities have affected the tourism demand.

${ }^{4}$ Traditional cultural festival in the northeast of Brazil that happens annually in June and consists on the highest season of the tourism in São Luís.

${ }^{5}$ One of the hotel groups investigated holds seven other hospitality firms—-hotels and flats—in São Luís, therefore, they are not included in the research universe (11 hotels).
} 
Table 1

Profile of Respondents and Hotels' Characteristics

\begin{tabular}{|l|l|l|l|l|l|l|l|}
\hline Respondent & Gender & Position & Education & Working period & $\begin{array}{l}\text { Scope of } \\
\text { network }\end{array}$ & Hotel category & $\begin{array}{l}\text { Date of } \\
\text { operations }\end{array}$ \\
\hline R1 & Fem. & $\begin{array}{l}\text { Operational } \\
\text { management }\end{array}$ & $\begin{array}{l}\text { Post } \\
\text { graduation }\end{array}$ & Seven years & International & Upscale & 1999 \\
\hline R2 & Fem. & HRM & $\begin{array}{l}\text { Post } \\
\text { graduation }\end{array}$ & Eight years & National & $\begin{array}{l}\text { Upscale, } \\
\text { mid-scale, and } \\
\text { economic }\end{array}$ & $1999 / 2010$ \\
\hline R3 & Masc. & $\begin{array}{l}\text { Operational } \\
\text { management }\end{array}$ & $\begin{array}{l}\text { Post } \\
\text { graduation }\end{array}$ & $\begin{array}{l}\text { One year and } \\
\text { three months }\end{array}$ & International & Mid-scale & 2009 \\
\hline R4 & Fem. & $\begin{array}{l}\text { General } \\
\text { management }\end{array}$ & $\begin{array}{l}\text { Post } \\
\text { graduation }\end{array}$ & $\begin{array}{l}\text { One year and } \\
\text { seven months }\end{array}$ & International & Economic & 2011 \\
\hline R5 & Masc. & Operation director & $\begin{array}{l}\text { Post } \\
\text { graduation }\end{array}$ & $\begin{array}{l}\text { One year and six } \\
\text { months }\end{array}$ & National & Upscale & 2009 \\
\hline
\end{tabular}

Note. Source: Elaborated by the authors from the field research.

The methodological technique to collect data was a semi-structured interview script whose results were submitted to a content analysis, allowing the identification of the main ideas in the entrepreneurs' answers, comparing them with theory (Richardson, 1999).

Following a systematic study, the investigation results will be discussed, concerning four key themes: leaders' understanding and CSR management, CSR practices in the hotels, CSR effects on the hotels, and HRM and employees' performance.

\section{Leaders' Understanding and CSR Management}

First of all, managers showed varied understandings of CSR practices, such as: the focus on employees, the respect of labor legislation, the creation of a safe and enjoyable workplace, fair staff salaries, and recognition awards. Besides that, it was mentioned selective waste collection and consumption reduction, as well as the relationship with surrounding communities, job and income opportunities, and local culture appreciation.

The respondents declared that there is no difficulty within the companies for the implementation of CSR, except for some cases that require the approval of investors. However, the urban infrastructural weaknesses, such as lack of selective waste collection and sanitation, are seen as a significant barrier. This assertion is supported by the speech of R4, understanding that, “The city's structure doesn't facilitate the implementation of actions. Selective waste collection, for example, we don't find companies to do this service, besides sanitation issues that directly impact the natural resources".

In most hotels investigated, the human resources manager is the person in charge of CSR development. At this point, there is a major issue, since authors such as Dias (2009) advocated that CSR cannot be a subculture inside the organization, but every employee in each sector must have a positive attitude towards it. Findings prove that within the hotels, the actions usually start as a decision of the human resource manager; therefore, some subunits get more encouraged than others, causing an unbalanced situation within the hotels which may make difficult the development of a social and environmental culture along the whole organization.

Although CSR is understood as a business strategy, leaders only communicate the socially responsible activities inside the hotels. Guests get to know these actions mainly through specific brochures left in the rooms, posters in the reception and hallways, or hotel websites. Only one manager said that he tries to publicize these actions to society through formal communication or advertisement. 


\section{CSR Practices in the Hotels}

According to the respondents, CSR is part of the network policy in which they are associated. It is seen as a strategy, because the general public demands that responsibility, guests perceive and value it, and the investment in employees is reversed into customer satisfaction. Thus, the hotels stand out in the market. In this respect, R5 said that:

[...] CSR is not philanthropy, but is a part of a business strategy. For a successful corporation, you need to re-educate the community, in general, to make a better environment for businesses, to generate more taxes and higher investments for the community and, consequently, to give the return to the project itself, through good employee performance and customer satisfaction.

CSR activities are usually related to environmental sustainability, such as selective waste collection, energy and water savings. In this discussion, R3 explained that, "In our corporate network, we must follow the international standard, so we need to implement some actions, otherwise we would miss the partnership". Therefore, the economic responsibility (Carroll, 1979), even though the primary purpose is not environmental sustainability, in fact, still brings positive results for the nature itself.

Focusing on the responsibility with employees, there are common attitudes in the hotels such as career promotion, trainings, medical plan, hotel staff functions with their families, overnight transport, building and maintaining a safe and enjoyable workplace, and aiming guest satisfaction in return. At this point, R5 confirmed that, "When we offer comfort and safety, clean uniforms, medical plans [...], these are not legal benefits, but interesting benefits that can cause motivation and bring good results".

Respondents cannot provide the precise amount of the investments in CSR. Some consider specific values invested in campaigns (US\$ 4,200.00) or percentage rates of the profits (1\%). Only one hotel highlighted the support for external projects, in the school district of some employees and sporadic philanthropic actions with other companies.

Another important matter refers to the organizational mobilization in CSR practices. Leaders engage their staff through evaluation meetings, everyday conversations, and internal communication. Moreover, the managers interviewed reiterate their obligations to lead the actions and encourage employees, such as R1 demonstrated, "Without a leadership commitment is not possible to have the necessary employees' level of engagement”. Furthermore, employees feel free to make suggestions, like donations, social events, and recycling projects.

\section{CSR Effects on the Hotels}

The main effects of CSR actions refer to employee satisfaction. Investors also assess the actions in a positive way, especially when they impact on costs such as energy consumption and laundry savings. For them, these actions impact on people's self-consciousness, contributing to their values.

Nobody identified relationship improvements with government agencies, adding that they are not interested in CSR issues. In R5's point of view, “Government agencies are not aligned to the theme of corporate social responsibility. They want to take political advantage of social actions. And entrepreneurs have only business interests, instead of political ones”.

In the respondents' opinions, when customers know the hotels' CSR measures, reading flyers or talking to employees, they recognize its importance and praise their initiative, especially specific travelers like the Europeans. The local hotel leaders argued that the Brazilian visitors have shown a growing collaboration 
regarding the reuse of sheets. On the other hand, managers claim that the benefits granted to employees are not publicized, therefore, guests, suppliers, partners, and society do not perceive them.

\section{HRM and Employees’ Performance}

Most leaders confirmed HRM programs within the organizations, especially because they must obey the standards of their chain operating companies. One of the managers interviewed emphasizes the importance of "recruitment, selection, evaluation, recognition, and remuneration” process. Another professional understands the association between HRM and organization's performance. In addition, R5 made a significant statement, proposing that, "Human resource management is a problem of every leader within the organization and not only of HR manager. It is not an isolate action or a program, but the company's culture”.

Table 2 presents the main implemented activities and those which, according to the respondents, if implemented, would improve employees’ performance and facilitate CSR programs.

Table 2

Summary of Actions Implemented/to be Implemented Within the Hotels

\begin{tabular}{|l|l|}
\hline \multicolumn{2}{|c|}{ Actions that stimulate/motivate employees' performance } \\
\hline Implemented & To be implemented \\
\hline Pleasant workplace maintenance with transparency and respect. & The offer of new courses and trainings. \\
\hline Available resting places. & More comfortable social areas. \\
\hline $\begin{array}{l}\text { Awards: worker of the month, targets achieved, and social } \\
\text { events. }\end{array}$ & Occupation and salary plans and higher remuneration. \\
\hline $\begin{array}{l}\text { Proper food and beverage offer, comfortable cafeteria, and food } \\
\text { stamps. }\end{array}$ & Medical plans and other benefits. \\
\hline Qualification policy with free trainings and courses. & $\begin{array}{l}\text { Operational processes enhancement providing a better } \\
\text { productivity. }\end{array}$ \\
\hline The increase in the number of leaders. & HRM programs. \\
\hline
\end{tabular}

Note. Source: Elaborated by the authors from the field research.

Based on the above, the progress in professionalization and in the quality of HRM programs improved the performance of employees in their workplaces. However, the hotels keep having problems with remuneration, occupation, and salary programs and continuous education for strategic levels.

An underlined quote identified in the investigation was the assertion of the respondents that HRM is crucial for the development of sustainable measures in the organization, added to the participation of all the hotel staff. R2 corroborated with this statement, reporting that:

When the HR manager is close to the employees [...] is so much easier to set up the actions. You improve relationship with them and, then, they easily embrace the ideas suggested, created, and accepted. You turn the group into a team.

At last, it is permitted to realize through the above discussion that HRM and CSR are interconnected. This is an essential link to develop sustainable practices in the organization, regardless of the main purpose of the company in implementing CSR.

\section{Conclusions}

This article intended to identify the hospitality industry challenges in São Luís, Maranhão, Brazil, to develop an organizational culture that enables the practice of CSR. This way, the leaders of national and international chain operating hotels of São Luís were investigated about their CSR/HRM comprehension and activities. 
The results of this research confirm that CSR is considered by managers as a business strategy whose benefits are mainly directed to the hotel staff, such as remuneration and career plans, rest and entertainment places, pleasurable work environments, awards, and recognition. Even though the hotels do not focus on publicizing these actions to society, the effects are perceived by guests through the quality of services provided. Managers understand that CSR activities, in addition to its strategic role, contribute to personal and professional fulfillment of employees.

CSR management is a responsibility of human resources departments or general managers within the investigated companies which may undermine the effectiveness in creating an organizational culture that, in fact, involves all sectors and employees. However, leaders must know that when trying to implement strategies leading to a new vision or objective, they will find that their strategies will fail if they are inconsistent with the organizational culture. Thus, leadership is essential to build a culture that embraces CSR as an everyday practice in hotels.

The outlined actions in Table 2 reveal problems in the reality of tourism and hospitality industry, enhancing a great challenge for the leadership in creating and maintaining organizational characteristics that reward and encourage collective efforts in developing CSR actions.

As a proposal for future studies, it is shown the interest to know the perspective of hotel employees on CSR issues, as well as verify if these practices occur in hotels with independent administration.

Finally, this article underlines that CSR is significantly linked to HRM, as soon as the relationship between employees and their leaders leads to a collective involvement in all the proposed actions.

\section{References}

Alves, T. J. C., \& Conto, S. M. D. (2009). Informações de hóspedes em relação a práticas ambientais como fator de escolha de um meio de hospedagem. Revista Hospitalidade, 6(2), 73-95.

Bowen, H. R. (1957). Responsabilidades Sociais do Homem de Negócios. Rio de Janeiro: Civilização Brasileira.

Carroll, A. B. (1979). A three-dimensional conceptual model of corporate performance. Academy of Management Review, 4(4), 497-505.

Coral, E. (2002). Modelo de planejamento estratégico para a sustentabilidade empresarial. Tese de Doutorado, Programa de Pós-Graduação em Engenharia da Produção, Universidade Federal de Santa Catarina UFSC, Florianópolis.

Correa, F. T. B. S., \& Medeiros, J. S. (2008). Responsabilidade corporativa para quem? Retrieved from http://www.ethos.org.br/docs/comunidade_academica/premio_ethos_valor/trabalhos/339_Filipe_e_Joao_Ricardo.doc

Dias, R. (2008). Introdução ao Turismo. São Paulo: Atlas.

Dias, R. (2009). Gestão Ambiental: Responsabilidade social e sustentabilidade (1st ed.). São Paulo: Atlas.

Figueira, V., \& Dias, R. (2011). A Responsabilidade Social no Turismo (1st ed.). Lisboa: Escolar Editora.

Fleury, A. C., \& Fleury, M. T. L. (2000). Estratégias empresariais e formação de competências. São Paulo: Atlas.

Goleman, D. (1995). Inteligência Emocional. Rio de Janeiro: Objetiva.

Guedes, R. D. C. (2000). Responsabilidade social e cidadania empresariais: Conceitos estratégicos para as empresas face à globalização. Dissertação (Mestrado em Administração de Empresas da Pontifícia Universidade Católica de São Paulo). São Paulo: PUC/SP.

Instituto Brasileiro de Geografia e Estatística [IBGE]. (2010). Censo 2010. Retrieved from http://censo2010.ibge.gov.br/en/

Judge, W. Q., \& Douglas, T. J. (1998). Performance implications of incorporating natural environmental issues into the strategic planning process: An empirical assessment. Journal of Management Studies, 35(2), 241-262.

Kruglianskas, I., Aliglere, L. A., \& Aliglere, L. (2009). Gestão socioambiental: Responsabilidade e sustentabilidade do negócio (1st ed.). São Paulo: Atlas.

Lage, B. H. G., \& Milone, P. C. (2001). Economia do Turismo (7th ed.). São Paulo: Atlas.

Maranhão. (2009). Secretaria de Estado de Turismo. Indicadores do Turismo. 
Melo Neto, F. P., \& Froes, C. (2001). Gestão da Responsabilidade Social Corporativa: O caso brasileiro. Rio de Janeiro: Qualitymark.

Montibeller Filho, G. (2004). O Mito do Desenvolvimento Sustentável: Meio ambiente e custos sociais no moderno sistema produtor de mercadorias (2nd ed.). Florianópolis: UFSC.

Pimenta, M. A. (2006). Gestão de pessoas em turismo: Sustentabilidade, qualidade e comunicação (2nd ed.). Campinas, SP: Alínea.

Richardson, R. J. (1999). Pesquisa social: Métodos e técnicas. São Paulo: Atlas.

Rocha-Pinto, S. R., Pereira, C. S., Coutinho, M. T. C., \& Johann, S. L. (2007). Dimensões funcionais da gestão de pessoas (9th ed.). Rio de Janeiro: Editora FGV.

Schermerhorn, J. R. (1999). Administração (5th ed.). São Paulo: Ed. LTC.

Schroder, D., \& Lourenço, A. G. (2003). Vale investir em responsabilidade social? Stakeholders, ganhos e perdas. In Responsabilidade Social das Empresas-A Contribuição das Universidades (Vol. 2). São Paulo: Editora Peirópolis.

Stoner, J. A. F., \& Freeman, R. E. (1985). Administração (5th ed.). Rio de Janeiro: Prentice-hall do Brasil.

Tonet, H. C., Bittencourt, F. R., Costa, M. E. B., \& Ferraz, V. N. (2012). Liderança e gestão de pessoas em ambientes competitivos. Rio de Janeiro: Editora FGV.

Vergara, S. C. (2005). Gestão de Pessoas (4th ed.). São Paulo: Atlas. 